\title{
METRICS OF PRESENTEEISM AND ITS RELATIONS WITH COOPERATION: AN EMPIRICAL EVIDENCE
}

\author{
GIOVANNA GARRIDO ${ }^{1}$ \\ (iD) https://orcid.org/0000-0002-7330-297X \\ MATEUS K. BORGES ${ }^{1}$ \\ (iD) https://orcid.org/0000-0003-0375-2382 \\ ROBSON S. BORGES ${ }^{1}$ \\ (iD) https://orcid.org/0000-0003-3660-9734 \\ MARCO A. SILVEIRA ${ }^{2}$ \\ (iD) https://orcid.org/0000-0002-2436-0364
}

To cite this paper: Garrido, G., Borges, M. K., Borges, R. S., \& Silveira, M. A. (2019). Metrics of presenteeism and its relations with cooperation: An empirical evidence. Revista de Administração Mackenzie, 20(2). doi:10.1590/1678-6971/eRAMG190107

Submission: May. 16, 2018. Acceptance: July 31, 2018.

1 Centro de Tecnologia da Informação Renato Archer (CTI), Campinas, SP, Brazil.

2 Centro Universitário Campo Limpo Paulista (UNIFACCAMP), Campo Limpo Paulista, SP, Brazil.

\section{(cc) BY




\section{ABSTRACT}

Purpose: Diagnose and quantify the presenteeism and its relations with cooperation in the reality of a public research organization.

Originality/value: This study is an initiative to face the current challenge of measuring presenteeism through inclusive approaches, providing actionable information about this behaviour and integrating multidisciplinary knowledge in order to understand the factors that influence it and the factors that are influenced by it, as well as how the presenteeism affects productivity at work.

Design/methodology/approach: The study was conducted in a public research organization with the purpose of to diagnose the reality of the organization in terms of presenteeism and cooperation by using analytical methods.

Findings: The following results were obtained: 1 . metrics on the general levels of presenteeism and cooperation; 2. levels of presenteeism and cooperation in each of the studied team; 3. correlations between presenteeism and cooperation; and 4. possible influence factors in the levels of presenteeism and cooperation. In summary, when recognizing the interconnectivity between presenteeism and cooperation and the relevance of a strategic management of the human capital that considers its specificities and integrates its biunivocal and inversely proportional content, this study presents empirical evidence that supports the relation between both phenomena and validates ways to diagnose and quantify their impacts in the organization.

\section{KEYWORDS}

Presenteeism. Cooperation. Human capital. Analytical methods. Productivity. 


\section{INTRODUCTION}

Due to the 21 st century's economic scenario, organizations have been required to develop competences in order to act and survive in competitive environments. The dynamic nature of markets and the increasing availability of information and technology impose to organizations the necessity to innovate continuously, aiming to increase competitiveness and focusing their efforts on organizational sustainability.

The managing challenge for sustainability implies dealing with multiple variables linked to tangible and intangible factors, of human, technological and organizational nature. In this context, the "profit by profit" has become a high-risk strategy, while intellectual capital becomes a strategic organizational asset (Hota \& Ghosh, 2013).

The intellectual capital can be understood as the set of intangible resources that organizations have at their disposal, which allows them to produce in an efficient and effective way. It is composed by three components: The structural capital, which involves organizational assets related to the intellectual property category; the relationship capital, that corresponds to the generation of knowledge resulted from relations with other organizations, clients and suppliers; and human capital, its main component that represents the knowledge and skills of employees at the disposal of the organization (Edvinsson \& Malone, 1998; Sveiby, 1998).

The emphasis given to human capital is due to the symbiotic personorganization integration that is recognized since the early days of studies on the importance of relations at work. In this way, efforts for mantaining the organizational sustainability over time should consider the importance of strategic alignment of human capital to the ideals of the organization and, at the same time, the need of a proficiency in its management (Momim \& Mishra, 2015; Silveira, Kikuchi, Lima, \& Silveira, 2015). This scenery makes the understanding of mutual relations between individuals and organizations one of the key factors in generating competitive advantages (Silveira, 2012).

Based on the axiom of managerial sciences "what can not be measured it can not be adequately managed" (Breyman \& Dolinskiy, 2016), the necessity of using data and analytical techniques to support decision-making has become evident to companies that are looking for a strategic management of the human capital. This need derives from its potential of improving both organizational competitiveness, since that it leads to greater confiability of results and better management of investments in human capital, and individual performance and development, due to the consistent approach to 
people (Bassi, 2011; Bodie, Cherry, Mccormick, \& Tang, 2016; Fitz-Enz, 2010; Gustafsson, 2012; Handa \& Garima, 2014; Mishra, Lama, \& Pal, 2016; Momim \& Mishra, 2015; Shah, Agarwal, Pollak, Dutta, \& Dunphy, 2015).

Given the scientific and technological difficulty of measuring many of the phenomenas related to human capital, the development of knowledge, tools and analytical methods to measure their impacts on the organization constitutes one of the major academic and business challenges, making the claim of this study an initiative with scientific and organizational relevance. Among these major challenges are efforts to understand and measure presenteeism, due to its impacts on the economic and operational performance of organizations, workers and society. The search for approaches that allow to diagnose and quantify the impacts of presenteeism has instigated efforts to investigate the multiple factors that influence and are influenced by it.

Since the systemic approach places presenteeism in the interface between personal and organizational factors (Garrido, Mendonça, Lopes, \& Silveira, 2017), this study aims to reinforce that approach considering the presenteeism as being socially constructed, and under the influence of social interactions and work dynamics (Calzaretta, 2007, Prochascka et al., 2012). For this purpose, this study focuses on the interconnectivity established between presenteeism and cooperation, considering it an inversely proportional relationship and whose impacts on the performance of companies are explored in the conceptual model of Garrido et al. (2017).

While presenteeism is perceived as an obstacle to increased productivity, cooperation is the opposite, since the more integrated the people are within their teams, the higher the productivity and the lower the propensity to behave as presentist. Thus, recognizing the relations between those both phenomena and the relevance of a strategic management that considers their specificities and, at the same time, integrates the biunivocal and inversely proportional content of this relation, this study is an empirical initiative whose objective is to diagnose and quantify the presenteeism and its relations with cooperation in the reality of a public research organization.

\section{THEORETICAL REFERENTIAL}

\subsection{Presenteeism: human capital in deficit}

In the area of organizational behavior, there is a great deal of research related to absenteeism and the establishment of policies aimed at mitigating 
absenteeism in organizations. However, although it is an impactful phenomenon for organizational performance, it is considered that strictly targeted attention to absenteeism is insufficient for the management of human capital. This is because this procedure is based on the assumption that being present at work is what guarantees productivity, ignoring cases where the individual is present at work, but unproductive (Johns, 2010; Lowe, 2002), which is the essence of presenteism.

Although it consists of a phenomenon in which manifestations go beyond what is measurable, presenteeism behaves as an evil even more pernicious than absenteeism. Even though silently, the presentist behavior has been considered a factor of strong impact on the economic performance of organizations (D’Abate \& Eddy, 2007; Hemp, 2004; Umann, Guido, \& Grazziano, 2012). This makes this study an important area of research, acting as a catalyst for theoretical advances that contribute to filling the gray area between absenteeism and total engagement (Johns, 2010; Lowe, 2002).

The point is that the recent scholarly conception of presenteism is limited to analytic biases that relate it only to aspects of worker health (Johns, 2010). Most of the studies on presenteeism regard it as strictly related to the disease, claiming to be a consequence of the inadequacy between the individual's ability to work in physical and mental terms, and the requirement of the task (Collins \& Cartwright, 2012; Taloyan et al., 2012; Umann, Guido, \& Silva, 2014). However, although this conception is also important in the study of presenteism, one can not exclude or discard other factors that are also influential in this behavior (Pereira, 2014).

Thus, to broaden approach, a conceptual boundary of presenteeism is assumed to be present at work, but absent in mind or behavior, so that performance is affected (D'Abate \& Eddy, 2007). That is, a behavior characteristic of an "invisible absence," in which the individual is present, but producing less than his/her potential would allow it to produce.

This conceptualization sums up the theoretical and practical ideal of this study, since it directs its analytic content to a view of presenteism as a behavior that is not strictly related to the disease but, regardless of the physical condition of the one who manifests it, it means a loss in terms of human capital.

The study directs the interpretation of presenteeism to an analytical bias that seeks to understand it, not only as something that arises solely from personal factors, but also from the interface between personal and organizational factors. Whether for structural, organizational and institutional issues, for organizacional enviroment susceptible to posture, or even for more 
implicit reasons, such as a way to deal with stress, the search for pleasure, by dissatisfaction or lack of meaning in the task performed, the worker is physically present at work but absent in mind, behavior and in capability of performing his tasks in a productive way. Aiming to reduce his own frustration and dissatisfaction and to satisfy his psychological needs and vices, he silently simulates his own performance (D'Abate, 2005; D'Abate \& Eddy, 2007; Eddy, D’Abate, \& Thurston, 2010; Ferreira \& Esteves, 2016; Page, 2015; Paulsen, 2015; Saarvala, 2006; Vijayakumar, 2015).

Paulsen (2015) subsidizes this debate about the influence of organizational and personal factors in presenteism, combining representative axes of worker subjectivity and work objectivity. Thus, two basic types of contexts are defined: the first one in which the presentist behavior is the result of personal factors and a second context in which the very irrationality of the work organization determines it, denoting the involuntary character of this behavior.

The study by Paulsen corroborates with studies that emphasize the relationships between the presentist behavior and the meaning of work (Eddy et al., 2012; Fritz, Ellis, Demsky, Lin, \& Guros, 2013; Fritz, Lam, \& Spreitzer, 2011; Page, 2015). According to the author, individual inclination to work is an endogenous phenomenon that does not come from management but depends on the meaning given to the work performed, making it more acute the less this meaning.

Likewise, in punctuating the need for free time for sustaining energies as a motivation for posture, Paulsen (2011) praises the way in which meaningful work softens the presentist tendency. The greater the meaning that the individual attributes to his work, the less is his need to detach himself from it to replenish energies (Fritz et al., 2013, Vitayakumar, 2015). Considering the affective state of the individual as a resource for work, in which the worker identifies with what he does, it is not the fact of distancing himself mentally or psychologically that will guarantee his well-being and satisfaction. Work itself is already a source of pleasure (Trougakos \& Hideg, 2009).

In summary, the motivations for the presentist behavior are diverse. Now they appear as a means of personal indignation, while other times, when implicit to the company and explicit among the workers, as a way to bring about change or, as a result of something already introjected in the culture of the company. Often, because of the way work is organized, the simulation becomes so integrated into the task that it induces passive resignation as an adjustment to one's own waste (Paulsen, 2011). Therefore, whether through apathy or as a manifestation of resistance, this behavior 
becomes a chronic illness that, by attenuating human capital, silently impacts organizational performance in all its aspects.

\subsection{Cooperation: socialization of knowledge and organizational superavit}

In the face of recognition of the social nature of the human being and the time spent at work, as well as the importance of work for personal wellbeing, health and happiness, the debates on relationships in the work environment and their potential impacts on both workers and organizational performance (Sobrinho \& Porto, 2012, Tamayo, 2004).

An organization is a social system where all work is collective, so the meaning given to human relations in this context exerts an effect both on the quality of the organizational environment and on its results (Prochaska et al., 2012; Silveira \& Becaro, 2015; Yang, Zhu, \& Xie, 2015). Among these, the relations of cooperation existing within the working groups and among these groups stand out.

From the profusion of existing studies results a diversity of conceptualizations and approaches on the phenomenon of cooperation. Mead (2003) defines it simply as the act of working together for the same purpose. Piaget (1998) sees it as a method that is based on reciprocity between individuals and that occurs through intellectual decentralization, having reason as a collective product, since there is construction, not only of moral but also rational norms. Cooperation is also understood as a process of interaction between individuals, or between groups, for shared benefit (Schalk \& Curşeu, 2010).

Although it is a still polysemic concept, the relevance given to this phenomenon is due to the fact that it is one of the most important topics for organizational sustainability. It is recognized that cooperative environments are effective sources of competitive advantage (Silveira \& Becaro, 2015), since they favor the fulfillment of the organizational objectives in favor of competitiveness with quality of life.

Based on these approaches, the present study sustains its purpose from a conceptual delimitation of cooperation as a relation of mutual aid in the work aiming at the accomplishment of common goals and objectives.

In the face of the increasingly technological development full and globalized, the relation between cooperation and sustainability is emphasized by the convergence between a cooperative environment and innovation, a key element in obtaining competitive advantages whose sine qua non is the generation of knowledge. 
Habermas (1992) adduces, by defending the parameter of critical rationality is no longer the cognizing subject that relates to an object, but the intersubjective relation that individuals establish between themselves, aiming to a better comprehension and manipulation of such object. Thus, this theory reinforces the intersubjective relationship among workers, seeking understanding and mutual assistance on a shared task or goal, consisting in a relation that generates knowledge.

Based on Habermas's theory, it is revealed that the human knowledge is created and expanded through social interaction. Therefore, a cooperation approach must take in consideration not only individual's characteristics, but also the whole shared perceptions of the workplace environment. Being a phenomenon related to human factors and established in an inherently social context, the quality of cooperative relation depends not only on personal factors, but also on their combination with organizational factors, since it is inevitably influenced by the organizational environment (Ramacciotti, 2007).

To summarize, in the face of the role exerced in generating and sharing knowledge, cooperative relations represent an inherent element to innovative processes and, consequently, a powerful active on obtaining organizational sustainability (Foray \& Lundvall, 1996; Nonaka \& Takeuchi, 1997; Silveira, 2013).

\subsection{Presenteeism and its relations to cooperation: towards diagnosis and quantification}

After acknowledging the range of presenteeism, an assertive management of this behavior requires approaches that provide ways to diagnose its manifestation (Lowe, 2002) and to measure its impacts on the individual and the competitive performance of the companies (Ospina, Dennett, Wayne, Jacobs, \& Thompson, 2015; Tang, 2014). Although efforts have been put into searching and how to measure it since 1992 (Pereira, 2014), the identification, understanding and measurement of this behavior and its effects on productivity still represent one of the greatest management challenges (John, 2010; Lowe, 2002).

Garrow (2016) presents the difficulty of measuring presenteeism as the first of the challenges related to the studies of this behavior. It is even argued that it is easier to measure its occurrence than its impact on productivity. In fact, although it consists of the key component for revenue generation (Prochaska et al., 2012), productivity is seen as an evasive concept of difficult measurement in many cases (Hemp, 2004; Mattke, Balakrishnan, Bergamo, \& Newberry, 2004). 
However, such difficulty also arises from the very limitations of the current models. Although there is already a variety of instruments that propose to evaluate and diagnose presenteeism (Ospina et al., 2015, Pereira, 2014, Prochaska et al., 2012), the identification of an ideal approach to measure it is accompanied by many challenges. There is often a certain confusion between the measurement of possible causes of the loss of productivity at work and presenteeism itself. Consequently, many of the available instruments, although not originally developed to quantify such behavior, are used for this purpose, generating serious methodological problems (Ospina et al., 2015).

Furthermore, currently prevailing instruments do not cover presenteeism in its whole. Through the already exposed academic conception that orientates the studies about this behavior, these instruments end up disregarding the phenomenon in its entirety, remaining focused only for measuring solely productivity losses resultant of physical condition (Hemp, 2004; Ospina et al., 2015), so the coverage and potentiality turn out to be insufficient to understand the array of factors that influence this behavior.

Therefore, to paraphrase Garrow (2016), the challenge imposed to the management is adherent of the own complexity. Resulting from a complex combination of organizational and human factors, it is the combination of qualitative and quantitative data that allows representing more precisely the way that presenteeism manifests itself in organizational reality.

Thus, the diagnosis and measurement of presenteeism and its effects on productive performance require both more inclusive approaches and methods of quantification. These, while providing actionable information about human behavior, should also integrate multidisciplinary knowledge for the holistic understanding of the multiple factors that influence and are influenced by presenteeism, affecting productivity at work (Garrow, 2016; Prochaska et al. 2012).

This is where the scientific and organizational relevance of this study lies in addressing the diagnosis and quantification of presenteeism and its relationship to cooperation. As explored in the study by Garrido et al. (2017), a systemic view of presenteeism allows us to consider cooperation as one of the main factors influencing and influenced by it.

On the one hand, due to its influence on stress and the consequent change in mood and demotivation, the lack of cooperative attitudes is established as the reason for the presentist behavior (Saarvala, 2006). The quality of the relationship and of the cooperation in the work acts in the replacement of the psychological resources because the more physically and psychologically energized, the less is the individual propensity to absent 
from work in mind or behavior (Fritz et al., 2011). Likewise, the presentist stance also negatively impacts cooperative attitudes and interpersonal relationships. Even if physically present, mental detachment and lack of focus on work preclude a healthy and constructive human relationship.

Thus, it is plausible to affirm that an integrative approach to measure productivity loss should consider the social interactions and dynamics of work (Prochaska et al., 2012), since presenteeism consists of a socially constructed phenomenon (Calzaretta, 2007). There is no doubt that positive relationships are responsible for energizing the individual both physically and psychologically (Sant'Anna, Moraes, \& Kilimnik, 2005). Lack of relationships absorbs psychological resources, affecting the quality of interpersonal relationships and cooperation at work. Consequently, the individual becomes prone to the presentist stance.

This, because it recognizes the interconnectivity between presenteeism and cooperation, and the relevance of a method of quantification of these phenomena that are still little studied, this study has the objective of diagnosing and quantifying the presenteeism and the cooperation, as well as the relations between them.

\section{METHODOLOGICAL PROCEDURES}

The study was conducted in a public research organization. For its execution, five teams were selected, being two research teams and three others that have the function of technical / financial / technological support to the researches carried out by the organization. In total, there were twentynine participants: employees and supervisors of each team.

Adopting an exploratory nature, this research aimed to diagnose the organizational reality in terms of presenteeism and cooperation. The proposed assessment looked for the following results:

- Metrics on the general levels of presenteeism and cooperation.

- Levels of presenteeism and cooperation in each of the studied teams.

- Correlations between presenteeism and cooperation.

- Possible influence factors in the levels of presenteeism and cooperation.

\subsection{Analytical dimensions}

The assessment based on the definition of analytical dimensions, being three of them constituted as dimensions of interest of the study and two as dimensions that influence them, approached as dimensions of influence. 
- Dimensions of interest: The study assumed presenteeism and cooperation as the two dimensions of interest. However, considering the cooperation range, it was considered pertinent that investigations should be more specific. Therefore, by methodological criteria, the cooperation dimension was subdivided into separated dimensions, namely: intra group cooperation and cooperation among groups. In this way, the subdivision enabled to consider three dimensions of interest: presenteeism, intra group cooperation and cooperation among groups.

- Dimensions of influence: As reasoned above, a competent human capital management is related to the search of understanding the mutual relation between individuals and organizations, considering the behaviour or posture as the result of correlations between human and organizational aspects. Likewise, being focused on two most important elements associated with the human capital, the proposed evaluation was summarized by adding to the dimensions of interest two dimensions of influence, namely: personal factors and organizational factors.

\subsection{Data collect}

Apart from the operationalization of research through application of questionnaires, the organization provided sociodemographic data about the participants, in which it was also studied the influence on the phenomena studied. However, the nature of the data demanded another methodological treatment, so it was decided to consider them as a special dimension of influence. Details about this dimension will be discussed later in the topic presented in Figure 3.3.3.

\subsection{Methodological description: evaluation steps}

To facilitate the analysis, the collected data were treated in the following way:

- association of indicators to a four-level measurement scale (0 to 3 points);

- consolidation of questionnaire data into numerical variables, being each associated to one of the analytical dimensions;

- consolidation of sociodemographic data provided by the organization into numerical variables, to enable analysis alongside other variables calculated. 
The treatment of the collected data enabled using of specific statistical techniques for each expected result, being respectively: 1. bootstrap; 2. arithmetic average; 3. correlation techniques; and 4. multiple linear regression. The software used to operate these techniques was RStudio.

- Evaluation indicators: To evaluate the reality of the organization regarded to each dimension, there were identified some research indicators. Figure 3.3.1 presents these indicators and their correspondence with each analysis dimension.

\section{(Figure 3.3.1)}

ANALYTICAL DIMENSIONS AND ASSOCIATED INDICATORS

\begin{tabular}{|c|c|}
\hline Dimensions of interest & Indicators \\
\hline \multirow{5}{*}{ Intra Group Cooperation } & Organizational Climate \\
\hline & Motivation \\
\hline & Workload \\
\hline & Confidence \\
\hline & Cooperation \\
\hline \multirow{4}{*}{ Cooperation Among Groups } & Organizational Climate \\
\hline & Cooperation \\
\hline & Motivation \\
\hline & Workload \\
\hline \multirow{4}{*}{ Presenteeism } & Presenteeism \\
\hline & Health and Safety at work \\
\hline & Performance \\
\hline & Non-work at work \\
\hline Dimensions of influence & Indicators \\
\hline \multirow{4}{*}{ Organizational Factors } & Organizational Climate \\
\hline & Management \\
\hline & Quality of Life at work \\
\hline & Training \\
\hline
\end{tabular}


(Figure 3.3.1 (conclusion))

ANALYTICAL DIMENSIONS AND ASSOCIATED INDICATORS

\begin{tabular}{|c|c|}
\hline Dimensions of influence & Indicators \\
\hline \multirow{5}{*}{ Organizational Factors } & Workload \\
\hline & Health and Safety at work \\
\hline & Sinergy of Relations \\
\hline & Presenteeism \\
\hline & Process Flow \\
\hline \multirow{5}{*}{ Personal Factors } & Motivation \\
\hline & Meaning of Work \\
\hline & Organizational Commitment \\
\hline & Attention \\
\hline & Satisfaction \\
\hline
\end{tabular}

Data collection was done through a questionnaire composed of closed questions. Following the recommendation of the literature, a pre-test of this research instrument was made to show possible flaws. In addition, in order to guarantee assertiveness in the application and a higher rate of responses, the questionnaire was made available after an alignment lecture involving the members of the participating teams and the unit's board of directors. Its availability was made individually via e-mail containing electronic link for access and the data collected were tabulated in electronic spreadsheets.

- Calculation of the variables associated to the analytical dimensions: Once the indicators were associated to a four-level measurement scale and organized according to the desired analytical dimensions, the variables associated to these dimensions were calculated. Figure 3.3.2 presents all five analytical dimensions and their associated variables. 


\section{(Figure 3.3.2)}

ANALYTICAL DIMENSIONS AND ASSOCIATED VARIABLES

\begin{tabular}{lcc}
\multicolumn{1}{c}{ Dimensions of Interest } & $\begin{array}{c}\text { Associated } \\
\text { Variables }\end{array}$ & $\begin{array}{c}\text { Possible Values } \\
\text { to Variables }\end{array}$ \\
\hline Presenteeism & V1 & $0 \leq \mathrm{Vn} \leq 1$ \\
\cline { 1 - 2 } Intra Group Cooperation & V2 & \\
\hline Cooperation Among Groups & V3 & \\
\hline Organizational Factors & $\equiv$ & \\
\hline Personal Factors & V4 & \\
\hline
\end{tabular}

Source: Elaborated by the authors.

Each variable was calculated by dividing the number of points effectively obtained in the analytical dimension by the total of possible points in that dimension. Therefore, the variables could assume any value between 0 and 1, as shown in the third column of Figure 3.3.2.

- Consolidation of the variables associated to the data provided by the organization: In addition to the data collected by the questionnaire, the study also added to the analysis some sociodemographic data about the participants that were made available by the organization, considering them also influential in presenteeism and cooperation. Thus, since they demanded a different methodological treatment related to the other dimensions, the sociodemographic data were tabulated and considered as seven special dimensions of influence. From each of them, numerical variables were consolidated in order to make possible analysis and statistical processing with other dimensions and their associated variables. Figure 3.3.3 presents the seven special dimensions of influence and their associated numerical variables. 
(Figure 3.3.3)

SPECIAL DIMENSIONS OF INFLUENCE AND ASSOCIATED VARIABLES

\begin{tabular}{lcc}
\hline $\begin{array}{c}\text { Special Dimensions } \\
\text { of Influence }\end{array}$ & $\begin{array}{c}\text { Associated } \\
\text { Variables }\end{array}$ & $\begin{array}{c}\text { Possible Values } \\
\text { to Variables }\end{array}$ \\
\hline Gender & V6 & $\{0,1\}$ \\
\hline Research or Support Team & V7 & $\{0,1\}$ \\
\hline Salary Range & V8 & $\{1,2,3,4\}$ \\
\hline Supervisor ou Collaborator & V9 & $\{0,1\}$ \\
\hline Educational Level & V10 & $\{1,2,3,4,5\}$ \\
\hline Age & V11 & {$[29 ; 60]$} \\
\hline Time in the Company & V12 & {$[5 ; 37]$} \\
\hline
\end{tabular}

Source: Elaborated by the authors.

\section{RESULTS AND ANALYSIS}

This topic presents the four results of the study. It is worth saying that these results consider cooperation as a dimension subdivided into intra group cooperation and cooperation among groups.

\subsection{Metrics on the general levels of presenteeism and cooperation}

After calculating the numerical variables associated to each dimension of interest - V1, V2 and V3 - it was applied the Bootstrap technique. As a conducive statistical technique to small samples, Bootstrap was applied with the intent of maximizing the inference capability of the sample studied.

The original sample was reorganized through the resampling (with replacement), from which a thousand subsamples were created. This allows estimating, with a stipulated level of error, a confidence interval associated with variables $\mathrm{V} 1, \mathrm{~V} 2$ and $\mathrm{V} 3$, to establish the general level of each dimensions of interest. The 95\% confidence intervals are shown in Figure 4.1.1. 


\section{(Figure 4.1.1)}

CONFIDENCE INTERVALS ASSOCIATED TO PRESENTEEISM AND COOPERATION

\begin{tabular}{ll}
\hline \multicolumn{1}{c}{ Dimensions of Interest } & Interval \\
\hline Presenteeism & $(25,9 \% ; 32,8 \%)$ \\
\hline Intra Group Cooperation & $(70,8 \% ; 81,5 \%)$ \\
\hline Cooperation Among Groups & $(49,2 \% ; 65,4 \%)$ \\
\hline
\end{tabular}

Source: Elaborated by the authors.

Considering Figure 4.1.1, it can be stated that, with 95\% probability, the general level of presenteeism in the organization studied is between $25.9 \%$ and $32.8 \%$, diagnosing a productivity loss between $26 \%$ and $33 \%$, approximately.

This counterintuitive diagnosis reveals the importance of searching quantification of the human factors impacts on the company. The organization studied is a national reference, being composed of well-paid and highly educated employees, facts that, at first glance, could indicate the absence of this loss contingent.

The presenteeism is considered one of the biggest problems related to human capital, with the aggravating factor that is the lack of knowledge about its manifestation and effects on the worker and on the competitive performance of the company. The inability to measure that behaviour and its associated productivity losses inhibits the establishment of effective policies for the best use and development of human capital.

On the other hand, the general level of intra group cooperation in the organization studied is between $70,8 \%$ e $81,5 \%$, while the level of cooperation among groups is between $49,2 \%$ e $65,4 \%$.

In the applied questionnaire, the cooperation dimensions were evaluated by the respondents about the cooperation level between them and their colleagues. Therefore, the resulting evaluation is a function of the quality of interpersonal relation in day-to-day work. Hence, considering the expressiveness of these relations is greater among the members of the same working group - since intra group cooperation is consistently greater than cooperation among groups - it is reasonable to infer that interpersonal relations in the organization studied are generally positive, since the evaluation of cooperation is consistently greater in the context in which there is a greater number of interactions. 


\subsection{Levels of presenteeism and cooperation in each of the studied team}

The levels of presenteeism and cooperation for each team were represented by the average of all the observations for each numerical variable associated to the dimensions of interest - V1, V2 and V3. Figure 4.2.1 shows these averages, considering that they return a value representative only of the group to which they refer.

\section{(Figure 4.2.1) \\ LEVELS OF PRESENTEEISM AND COOPERATION IN EACH OF THE STUDIED TEAM}

\begin{tabular}{lccccc}
\hline \multirow{2}{*}{ Dimension of Interest } & \multicolumn{5}{c}{ Team } \\
\cline { 2 - 6 } & $\begin{array}{c}1 \\
\text { (Support) }\end{array}$ & $\begin{array}{c}2 \\
\text { (Research) }\end{array}$ & $\begin{array}{c}3 \\
\text { (Research) }\end{array}$ & $\begin{array}{c}4 \\
\text { (Support) }\end{array}$ & $\begin{array}{c}5 \\
\text { (Support) }\end{array}$ \\
\hline Presenteeism & $29,20 \%$ & $31,00 \%$ & $31,70 \%$ & $37,80 \%$ & $21,10 \%$ \\
\hline Intra Group Cooperation & $89,20 \%$ & $80,50 \%$ & $76,10 \%$ & $67,80 \%$ & $68,10 \%$ \\
\hline Cooperation Among Groups & $52,80 \%$ & $65,90 \%$ & $63,00 \%$ & $40,70 \%$ & $53,70 \%$ \\
\hline
\end{tabular}

Source: Elaborated by the authors.

According to the Figure 4.2.1, team 5 represented the lower level of presenteeism $(21,1 \%)$, an advantageous feature for the organization, since lower levels of presenteeism denote lower productivity loss records.

Otherwise, team 4 revealed the highest productivity loss record (37.8\%). Unsurprisingly, this is the team with lowest intra group cooperation and cooperation among groups records ( $67.8 \%$ and $40.7 \%$, respectively). Similarly, team 1 denotes the highest intra group cooperation level (89.2\%) and represents one of the lowest rates of productivity loss, which indicates the existence of a relation between the dimensions of interest.

\subsection{Correlations between presenteeism and cooperation}

Once the general and specific levels associated with the three dimensions of interest in this study were calculated and the relation between presenteeism and cooperation was diagnosed, the study sought to fetch in depth the relation between both phenomena.

Therefore, understanding both phenomena not only relate to each other but are also influenced by personal and organizational aspects, an assertive 
investigation of the relation between presenteeism and cooperation required the variables combination associated to them - V1, V2 and V3 - to the variables associated to organizational and personal influential factors - V4 and V5. Hence, the correlation technique was applied in order to better understand the relation between dimensions of interest and dimensions of influence. Figure 4.3.1 presents the results of the correlations. It is important to emphasize that the exposed relations are directly proportional, when represented in blue, and inversely proportional, when represented in red. Likewise, the intensity of the correlation is represented by the size of the points.

\section{(Figure 4.3.1)}

\section{CORRELATIONS BETWEEN THE VARIABLES ASSOCIATED TO DIMENSIONS OF INTEREST AND DIMENSIONS OF INFLUENCE}

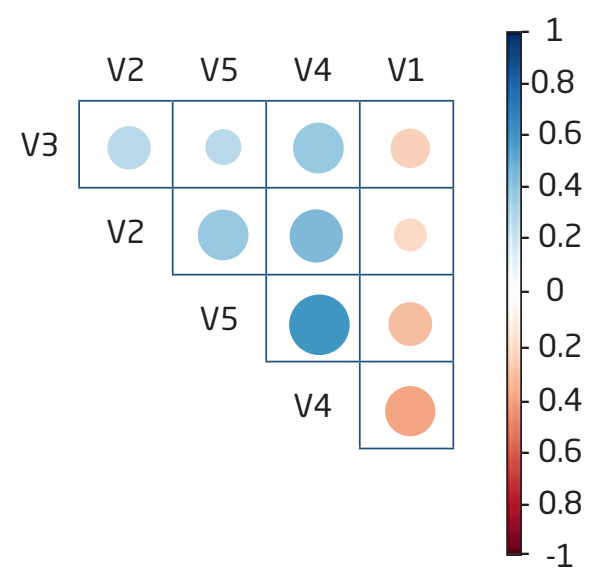

Source: Elaborated by the authors

The results of the correlations confirm that presenteeism and cooperation are opposite dimensions. Presenteeism appears as a factor that limits both cooperation dimensions, and vice versa. This finding corroborates with the avowed previously about team 4; the inversely proportional relation between presenteeism and cooperation explains the fact that a team with the highest productivity loss record $(37.8 \%)$ has the lowest intra group cooperation and cooperation among groups ( $67.8 \%$ and $40,7 \%$, respectively). Likewise, it is justified that a team that denotes a higher intra group cooperation level $(89.2 \%)$ represents the lowest productivity loss, such as team 1.

Furthermore, the correlation analysis allows claiming that the selfevaluation of respondents is consonant to the theoretical base established in this study about the influence of personal and organizational factors on 
presenteeism and on the degree of cooperation and integration of the teams. It should be noted that the variables V4 and V5 have a proportional direct impact on cooperation and they are inversely proportional to presenteeism.

An interesting detail in this result is the intensity of the correlation between the variable V4 and the variables V1, V2 and V3, denoting that, in the reality of the organization, presenteeism and cooperation are associated to organizational factors. It means that the organizational features are conducive to cooperative relations, a very favourable finding. However, this result explicitly indicates presenteeism as an involuntary behaviour. That is, the organization itself seems to be responsible for the overall rate of productivity loss diagnosed among employees.

In any case, such findings require further investigation in order to know not only the relation and statistical associations between variables, but also the causal relationships between them. After all, correlations do not imply causality, which means that the results of the correlations may or may not indicate the causal relationship between the dimensions considered.

\subsection{Possible influence factors in the levels of presenteeism and cooperation}

After diagnosing the correlations between presenteeism and cooperation, the study investigated the possible factors that influence them, in order to identify causal relations between the considered variables. For this purpose, the study applied the multiple linear regression technique.

As a collection of statistical techniques to develop models that describe relations among the explanatory variables of a given process, multiple linear regression showed potential to diagnose the degree of influence of each dimension of influence and special dimension of influence on the dimensions of interest.

Allowing calculating the coefficients associated to the variables that influence presenteeism and cooperation - V4, V5, V6, V7, V8, V9, V10, V11 and $\mathrm{V} 12$-, the multiple linear regression enabled to define specific predictive models that list which of the variables are more representative for the measurement of each phenomenon.

Figure 4.4.1 presents the presenteeism model, making explicit its influential variables and their intensities. It is valid to say that, in this model and in the subsequent ones, the influences are directly proportional, when represented by the $(+)$ signal, and inversely proportional, when represented by the (-) signal. 


\section{(Figure 4.4.1) \\ PRESENTEEISM MODEL}

\begin{tabular}{|c|c|}
\hline \multirow{3}{*}{ Presenteeism } & $\begin{array}{l}\text { Presenteeism = 0,6687 - 0,6018 x (Organizational Factors - 0,0063 x } \\
\text { (Time in the Company) }\end{array}$ \\
\hline & $\begin{array}{l}\text { Presenteeism = 0,6687 - 0,6018 x (Organizational Factors) - 0,0063 x } \\
\text { (Time in the Company) + 0,1655 x (if feminine gender) }\end{array}$ \\
\hline & $\begin{array}{l}\text { Presenteeism = 0,6687 - 0,6018 x (Organizational Factors) - 0,0063 x } \\
\text { (Time in the Company) + 0,1874 x (if research team) }\end{array}$ \\
\hline
\end{tabular}

Source: Elaborated by the authors

In agreement with the correlations analysis (Figure 4.3.1), organizational factors consist in a dimension of greater influence in presenteeism level, evidencing the theoretical reference about the ways in which the organizational features may induce such behaviour.

In addition, the model demonstrates that time in the company also consists in an influential dimension on presenteeism. Although the coefficient that multiplies this dimension is small - which leads to think that its potential influence is smaller - it contemplates natural values ranging from five to 37. It means that, when comparing a person who has been in the company for five years with another one who has been for 37 years, the enhancement of the level of presenteeism would be approximately 20 percentage points. Hence, the model argues that the level of presenteeism decreases as increases the time in the company.

Gender also appears as a dimension of influence, and allows identifying that, in the reality of the organization studied, presenteeism is more perceived among women. Likewise, the model shows that presenteeism tends to be more frequent in research teams than in support teams.

Figure 4.4.2 shows the result of regression for the intra group cooperation dimension, denoting the specific predictive model to this phenomenon.

(Figure 4.4.2)

INTRA GROUP COOPERATION MODEL

\begin{tabular}{ll}
\hline \multirow{2}{*}{$\begin{array}{l}\text { Intra Group } \\
\text { Cooperation }\end{array}$} & $\begin{array}{l}\text { Intra Group Cooperation = 0,3229 + 0,7378 x (Personal Factors) - 0,0069 x } \\
\text { (Time in the Company) }\end{array}$ \\
\cline { 2 - 2 } & $\begin{array}{l}\text { Intra Group Cooperation = 0,3229 + 0,7378x(Personal Factors) - 0,0069 x } \\
\text { (Time in the Company) - 0,1091 x (If feminine Gender) }\end{array}$ \\
\hline
\end{tabular}

Source: Elaborated by the authors. 
Before explaining the model, it is worth clarifying how the numerical value is associated to this dimension and how it should be interpreted. The questionnaire is associated to this dimension allowed identifying the assessment of the respondents with regards to cooperative relations in their groups, regardless of their own cooperative skills. Therefore, the numerical value associated to this dimension should not be considered as a value that represents the capability or intensity of cooperation of the respondents, but rather the way in which they jointly evaluate the cooperative interactions existing in their group.

Although Figure 4.3.1 demonstrates a clear and positive correlation between intra group cooperation and organizational factors, the regression did not show the causality between both dimensions. The model presents personal factors as the main influence on this dimension of interest, demonstrating the degrees of cooperation and integration within a team depends more on the personal features of those who compose it than on organizational features.

As well as the presenteeism model, time in the company also consists in an influential factor on the level of cooperation. It means that cooperation assessment decreases as the time in the company increases. According to the model (Figure 4.4.2), gender also appears as a dimension of influence. It is observed that women tend to evaluate intra group cooperation at a lower level than men, which could mean that, in this organization, women tend to be less satisfied with their group's cooperative environment.

Finally, Figure 4.4 .3 presents the possible factors of influence on the level of cooperation among groups.

\section{(Figure 4.4.3)}

\section{COOPERATION AMONG GROUPS MODEL}

\begin{tabular}{|c|c|}
\hline \multirow{6}{*}{$\begin{array}{l}\text { Cooperation } \\
\text { Among Groups }\end{array}$} & Cooperation Among Groups = -2,5104 + 1,227 x (Organizational Factors) \\
\hline & Cooperation Among Groups = -2,5104 + 1,227 x (Organizational Factors $)$ \\
\hline & + 0,6226 x (If Salary Range 2) ou \\
\hline & + 0,7642 x (If Salary Range 3) ou \\
\hline & + 1,1782 x (If Salary Range 4) \\
\hline & $\begin{array}{l}\text { Cooperation Among Groups = -2,5104 + 1,227 x (Organizational Factors) } \\
\text { - 0,2143 x (If feminine Gender) }\end{array}$ \\
\hline
\end{tabular}


Similarly, to intra group cooperation, the numerical value associated to this dimension should not be considered as a value that represents the capability or intensity of the respondents' cooperation with other groups, but rather the way in which they jointly evaluate the cooperative interactions existing among the different groups of the organization.

Unlike intra group cooperation model, the multiple linear regression substantiated the correlation between organizational factors and cooperation among groups (Figure 4.3.1). Indeed, organizational factors appears as the main influence on this dimension of interest. However, although Figure 4.3.1 demonstrates a clear positive correlation between cooperation among groups and personal factors, the regression model did not show causality between both dimensions. It suggests that good relations between different groups depend on the environment of the organization and its general characteristics.

Furthermore, salary range also consists in an influential dimension on the cooperation among groups. The model demonstrates that the intensity of this relation increases as the salary increases, indicating that individuals with higher remuneration tend to be more satisfied with the cooperation among groups. Likewise, in the organization studied, women tend to be less satisfied with the level of cooperation among groups, since the model also represents gender as an influential factor on this dimension of interest.

\section{FINAL CONSIDERATIONS}

The scientific and organizational relevance of this study is based on its potential contribution to overcome the current challenge of diagnosing and measuring presenteeism through inclusive approaches that integrate multidisciplinary knowledge to understand the multiple factors that influence and are influenced by it.

Having recognized the interconnectivity between presenteeism and cooperation, as well as the importance of a strategic human capital management that considers their specificities, this study aimed to diagnose and quantify those phenomena in the reality of a public research organization.

The methological criteria of the study involved the use of metrics and analytical techniques that allowed to diagnose the following results: 1. metrics on the general levels of presenteeism and cooperation; 2. levels of presenteeism and cooperation in each of the studied team; 3. correlations between presenteeism and cooperation; and 4. possible influence factors in the levels of presenteeism and cooperation. In summary, in approaching 
them according to the proposed methodology, the study grounded empirical evidence of the relationship between presenteeism and cooperation, as well as validated the methods that allow us to diagnose and quantify their impacts on organizational reality.

The results of the presented study can subsidize new management paradigms that use the potential gains that the understanding of the relationship between the two studied phenomenas provided, as well as to subsidize new studies that deepen the initial results presented here. Due to its characteristics, the methodology used may be also useful in studies that require the collection and treatment of large amounts of data, such as those involving several intra and interorganizational systems. In addition, through the sequential consolidation of the dimensions of interest in research variables, the study may support the monitoring of the phenomena studied over time.

Regarding the limitations of the study, the sample size used indicates the need for future improvements in the methodology through its application using larger samples. Moreover, because the study has been restricted to an organization of a specific sector of activity, the extrapolation of this data to any other sector lacks foundation.

It is also important to highlight that all the metrics of this work was based on sociodemographic data made available by the organization and on the perception of each respondent, not evaluating the merits of the answers and, neither, the practices adopted. Thus, the main contribution of this research is to make an initial diagnosis of the reality of the organization studied, subsidizing subsequent research to deepen the most relevant issues that were addressed in this research.

\section{MÉTRICAS DO PRESENTEÍSMO E SUAS RELAÇÕES COM A COOPERAÇÃO: UMA EVIDÊNCIA EMPÍRICA}

\section{RESUMO}

Objetivo: Diagnosticar e quantificar o presenteísmo e suas relações com a cooperação na realidade de uma organização pública de pesquisa.

Originalidade/valor: Este estudo é uma iniciativa frente ao atual desafio de mensuração do presenteísmo através de abordagens inclusivas que, ao mesmo tempo que sejam específicas em prover informações acionáveis 
acerca do comportamento presenteísta, integrem conhecimentos multidisciplinares para o entendimento dos fatores que influenciam e são influenciados por ele, afetando a produtividade no trabalho.

Design/metodologia/abordagem: O estudo realizou-se em uma organização pública de pesquisa, com o propósito de diagnosticar a realidade da organização em termos de presenteísmo e cooperação por meio da aplicação de métodos analíticos.

Síntese dos principais resultados: Foram diagnosticados os seguintes resultados: 1. metricas sobre os níveis gerais de presenteísmo e cooperação; 2. níveis de presenteísmo e cooperação por equipe estudada; 3. correlações entre o presenteísmo e a cooperação; e 4. possíveis fatores de influência nos níveis de presenteísmo e cooperação. Em síntese, por reconhecer a interconectividade entre o presenteísmo e a cooperação e a relevância de uma gestão estratégica do capital humano que considere suas especificidades e integre seu teor biunívoco e inversamente proporcional, este estudo apresenta evidências empíricas que fundamentam a relação entre ambos os fenômenos e validam meios para diagnosticar e quantificar seus impactos na organização.

\section{PALAVRAS-CHAVE}

Presenteísmo. Cooperação. Capital humano. Métodos analíticos. Produtividade.

\section{REFERENCES}

Bassi, L. (2011). Raging debates in HR Analytics. People \& Strategy, 34(2), $14-18$.

Bodie, M. T., Cherry, M. A., Mccormick, M. L., \& Tang, J. (2016). The law and policy of People Analytics. Legal Studies Research Paper Series, (6).

Breyman, I., \& Dolinskiy, A. (2016). Introdução ao People Analytics. Coursera, MIPT - Moscow Institute of Physics and Technology.

Calzaretta, A. V. (2007). Presentismo Laboral. Ciencia \& Trabajo, 24(9).

Collins, A., \& Cartwright, S. (2012). Why come into work ill? Individual and organizational factor underlying presenteeism. Employee Relation, 34(4), 429-442. doi:10.1108/01425451211236850 
D'Abate, C. P. (2005). Working hard or hardly working: A study of individuals engaging in personal business on the job. Human Relations, 58(8), 1009-1032. doi:10.1177/0018726705058501

D'Abate, C. P., \& Eddy, E. R. (2007). Engaging in personal business on the job: Extending the presenteeism construct. Human Resource Development Quarterly, 18(3), 361-383. doi:10.1002/hrdq.1209

Eddy, E. R., D'Abate, C. P., \& Thurston Jr, P. W. (2010). Explaining engagement in personal activities on company time. Personnel Review, 39(5), 639-354. doi:10.1108/00483481011064181

Edvinsson, L., \& Malone, M. S. (1998). Capital intellectual. São Paulo, SP: Makron.

Ferreira, A. I., \& Esteves, J. D. (2016). Perceptions of time at work. Personnel Review, 45(1), 29-50. doi:10.1108/PR-02-2014-0033

Fitz-Enz, J. (2010). The new HR Analytics: Predicting the economic value of your company's human capital investments. New York, NY: Amacom.

Fritz, C., Ellis, A. M., Demsky, C. A., Lin, B. C., \& Guros, F. (2013). Embracing work breaks: Recovering from work stress. Organizational Dynamics, 42, 274-280. doi:10.1016/j.orgdyn.2013.07.005

Fritz, C., Lam, C. F., \& Spreitzer, G. M. (2011). It's the little things that matter: An examination of knowledge workers' energy management. The Academy of Management Perspectives, 25(3), 28-39.

Foray, D., \& Lundwall, B. A. (1996). The knowledge-based economy: From economics of knowledge to the learning economy. In Employment and growth in the knowledge-based economy. Paris, FR: OECD.

Garrido, G., Mendonça, A. V., Lopes, K. M. O. L., \& Silveira, M. A. (2017). Presenteísmo: Causas e consequências de um mal subterrâneo. Revista de Ciências da Administação, 19(48), 54-67.

Garrow, V. (2016). Presenteeism: A review of current thinking. Brighton, UK: Institute for Employment Studies. Retrieved from http://bit.ly/2tLrrWH

Gustafsson, D. (2012). Business intelligence, analytics and human capital: Current state of workforce analytics in Sweden (Undergraduation monographie). University of Skövde. Skövde, Sweden.

Habermas, J. (1992). Teoría de la acción comunicativa (vol. I). Madrid, ES: Taurus. Handa, D., \& Garima. (2014). Human resource (HR) Analytics: Emerging trend in HRM. International Journal of Research in Commerce $\mathcal{E}$ Management, 5(6), 59-62. 
Hemp, P. (2004). Presenteeism: At work - but out of it. Harvard Business Review, 82, 49-58.

Hota, J., \& Ghosh, D. (2013). Workforce analytics approach: An emerging trend of workforce management. AIMS International Journal of Management, $7(3), 167-179$.

Johns, G. (2010). Presenteeism in the workplace: A review and research agenda. Journal of Organizational Behavior, 31, 519-542. doi:10.1002/job.630

Lowe, G. (2002). Here in body, absent in productivity. Canadian HR Reporter, 2. Retrieved from http://bit.ly/2G9f2yb

Mattke, S., Balakrishnan A., Bergamo, G., \& Newberry, S. J. (2004). A review of methods to measure health-related productivity loss. The American Journal of Managed Care, 13(4), 211-217.

Mead, M. (2003). Cooperation and competition among primitive peoples. New Brunswick, NB: Transaction Publishers.

Mishra, S. N., Lama, D. R., \& Pal, Y. (2016). Human Resource Predictive Analytics (HRPA) for HR management in organizations. International Journal of Scientific \& Technology Research, 5(5), 33-35.

Momim, W. Y. M., \& Mishra, K. (2015). HR analytics as a strategic workforce planning. International Journal of Applied Research, 1 (4), 258-260.

Nonaka, I., \& Takeuchi, H. (1997). Criação do conhecimento na empresa: Como as empresas japonesas geram a dinâmica da inovação. Rio de Janeiro, RJ: Campus.

Ospina, M. B., Dennett, L., Wayne, A., Jacobs, P., \& Thompson, A. H. (2015). A systematic review of measurement properties of instruments assessing presenteeism. The American Journal of Managed Care, 21 (2), 171-185.

Page, D. (2015). Teacher's personal web use at work. Behavior \& Information Technology, 34(5), 443-453. doi:10.1080/0144929X.2014.928744

Paulsen, R. (2011). Layers of dissent: The meaning of time appropriation. Outlines. Critical Practice Studies, 13(1), 53-81.

Paulsen, R. (2015). Non-work at work: Resistance or what? Organization, 22(3), 351-367. doi:10.1177/1350508413515541

Pereira, N. C. (2014). Presenteísmo odontológico: conhecendo um instrumento de pesquisa para mensuração e avaliação (Master's thesis). Universidade de São Paulo, São Paulo, SP, Brazil.

Piaget, J. (1998). Sobre a pedagogia. São Paulo, SP: Casa do Psicólogo.

Prochaska, J. O. et al. (2012). The well-being assessment for productivity: A well-being approach of presenteeism. Journal of Occupational and Environmental Medicine, 53(7), 735-742. doi:10.1097/JOM.0b013e3182 22af48. 
Ramacciotti, C. (2007). A ética e a confiança nas organizações: um estudo descritivo junto a profissionais da grande São Paulo (Doctoral dissertation). Fundação Getúlio Vargas, São Paulo, SP, Brazil.

Saarvala, E. (2006). Presenteeism: The latest attack on economic and human productivity. Human Resources Management, 2006.

Sant'Anna, A. S., Moraes, L. R. F., \& Kilimnik, Z. M. (2005). Competências individuais, modernidade organizacional e satisfação no trabalho: Um estudo de diagnóstico comparativo. Revista de Administração de Empresas, 4(1). doi:10.1590/S1676-56482005000100001

Schalk, R., \& Curşeu, P. L. (2010). Cooperation in organizations. Journal of Managerial Psychology, 25(5), 453-459. doi:10.1108/02683941011048364

Shah, N., Agarwal, R., Pollak, S., Dutta, R., \& Dunphy, K. (2015). Trends in people analytics. London, UK: PricewaterhouseCoopers. Retrieved from pwc.to/21Te0ds

Silveira, M. A. (2012). Gestão estratégica para a sustentabilidade organizacional: Capital humano e os processos de inovação e aprendizagem. In M. A. Silveira (Org.), Gestão da sustentabilidade organizacional: Inovação, aprendizagem e capital humano (pp. 21-46). Campinas, SP: Cedet.

Silveira, M. A. (2013). Relações cooperativas e socialização de conhecimento: Fundamentos da inovação e da sustentabilidade organizacionais. Congresso Latino-Iberoamericano de Gestão de Tecnologia 15, Porto.

Silveira, M. A., \& Becaro, T. C. (2015). Competitividade com qualidade de vida: Estratégias e práticas baseadas na valorização do fator humano nas organizações. In M. A. Silveira \& T. C. Becaro (Org.), Competitividade com qualidade de vida: O capital humano como fator de produção (pp. 21-37). Campinas, SP: Cedet.

Silveira, M. A., Kikuchi, L. S., Lima, A. S., \& Silveira, R. D. (2015). Inovação e aprendizagem organizacional: Abordagem TCD para desenvolvimento de competências em empresa do setor eletrônico. Congresso Latino-Iberoamericano de Gestão de Tecnologia 16, Porto Alegre.

Sobrinho, F. R., \& Porto, J. B. (2012). Bem-estar no trabalho: Um estudo sobre suas relações com clima social, coping e variáveis demográficas. Revista de Administração Contemporânea, 16(2), p. 253-270.

Sveiby, K. E. (1998). A nova riqueza das organizações: Gerenciando e avaliando patrimônios do conhecimento. Rio de Janeiro, RJ: Campus.

Tamayo, A. (2004). Introdução. In A. Tamayo (Ed.), Cultura e saúde nas organizações. Porto Alegre, RS: Artmed. 
Tang, K. (2014). Estimating productivity costs in health economic evaluations: A review of instruments and psychometric evidence. Pharmaco Economics, 33(1), 31-48. doi:10.1007/s40273-014-0209-z

Taloyan, M. et al. (2012). Sickness presenteeism predicts suboptimal selfrated health and sickness absence: A nationally representative study of the Swedish working population. PLOS ONE, 7(9). doi:10.1371/journal.pone. 0044721

Trougakos, J. P., \& Hideg, I. (2009). Momentary work recovery: The role of within-day work breaks. Current perspectives on job-stress recovery: Research in Occupational Stress and Well Being, 7, 37-84. doi:10.1108/S1479-3555(2009) 0000007005

Umann, J., Guido, L. A., \& Grazziano, E. S. (2012). Presenteísmo em enfermeiros hospitalares. Revista Latino-Americana de Enfermagem, 20(1). doi:10.1590/S0104-11692012000100021

Umann, J., Guido, L. A., \& Silva, R. M. (2014). Estresse, coping e presenteísmo em enfermeiros que assistem pacientes críticos e potencialmente críticos. Revista da Escola de Enfermagem da USP, 48(5), 891-898. doi:10.15 90/S0080-6234201400005000016

Vijayakumar, P. B. (2015). Work-life balance, identity salience and break taking behaviors in Indian expatriates (Master's thesis). University of Tennessee, Chattanooga, TN, USA.

Yang, T., Zhu, M., \& Xie, X. (2016). The determinants of presenteeism: A comprehensive investigation of stress-related factors at work, health, and individual factors among the aging worforce. Journal of Occupational Health, 58, 23-35. doi:10.1539/joh.15-0114-OA

\section{AUTHOR NOTES}

Giovanna Garrido, Postgraduate Program in Production Engineering (PPGEPS), Universidade Federal de São Carlos (UFSCar); Mateus K. Borges, Mathematics, Statistics and Scientific Computation Institute (IMECC), Universidade Estadual de Campinas (Unicamp); Robson S. Borges, Mathematics, Statistics and Scientific Computation Institute (IMECC), Universidade Estadual de Campinas (Unicamp); Marco A. Silveira, Faculty of Mechanical Engineering, Universidade Estadual de Campinas (Unicamp).

Giovanna Garrido is now CNPq Research Grant Holder (Brazil) in the Business Management Division at Centro de Tecnologia da Informação Renato Archer (CTI); Mateus K. Borges is now CNPq Research Grant Holder (Brazil) in the Business Management Division at Centro de Tecnologia da Informação Renato Archer (CTI); Robson S. Borges, is now CNPq Research Grant 
Holder (Brazil) in the Business Management Division at Centro de Tecnologia da Informação Renato Archer (CTI); Marco A. Silveira is now Teaching Researcher at the Postgraduate Program in Administration at Centro Universitário Campo Limpo Paulista (Unifaccamp).

Correspondence concerning this article should be addressed to Giovanna Garrido, Rodovia Dom Pedro I (SP-65), Km 143,6, Amarais, Campinas, São Paulo, SP, Brazil, CEP: 13069-901.

E-mail: giovanna.garrido@cti.gov.br

\section{$\int$ ACKNOWLEDGMENT}

To the Grupo de Apoio à Inovação e à Aprendizagem Organizacional (GAIA) [Group of Support to the Innovation and Organizational Learning] of the Centro de Tecnologia da Informação Renato Archer [Renato Archer Information Technology Center], to the Conselho Nacional de Desenvolvimento Científico e Tecnológico (CNPq) [National Council of Scientific and Technological Development], as well to the representatives of the public organization of research mentioned in this paper, by the opening granted for the realization of the study.

EDITORIAL BOARD

Editors-in-chief

Janette Brunstein

Silvio Popadiuk

Associated Editor

Fabiano Larentis

Technical Support

Vitória Batista Santos Silva

\section{EDITORIAL PRODUCTION}

Publishing Coordination

Irina Migliari

Layout Designer

Copyeditor

Irina Migliari (English)

Carlos Villarruel (Portuguese)

Language Editor

Daniel de Almeida Leão (English)

Irina Migliari (Portuguese)
Emap

Graphic Designer

Libro 